\title{
Quality characteristics of tomato 'Soksungjang' prepared with Rhizopus oligosporus Koji
}

\author{
Sung-Hee Jeon ${ }^{1}$, Young Youn ${ }^{1}$, Do-Youn Jeong ${ }^{2}$, Young-Soo Kim* \\ ${ }^{1}$ Food Research and Development Team, Imsil Cheese and Food Research Institute, Imsil 55918, Korea \\ ${ }^{2}$ Microbial Institute for Fermentation Industry (MIFI), Sunchang 56048, Korea \\ ${ }^{2}$ Department of Food Science and Technology, Jeonbuk National University, Jeonju 54896, Korea
}

\section{Rhizopus oligosporus Koji를 이용한 토마토 속성장의 품질 특성}

\author{
전성희 ${ }^{1} \cdot$ 윤영 $^{1} \cdot$ 정도연 ${ }^{2} \cdot$ 김영수 ${ }^{3 *}$ \\ ${ }^{1}$ (재)임실치즈앤식품연구소 식품개발팀, ${ }^{2}$ (재)발효미생물산업진흥원, \\ 3전북대학교 식품공학과
}

\begin{abstract}
This study aimed to investigate and optimize the quality of tomato 'Soksungjang'. Tomato 'Soksungjang' was prepared using $10 \%$ tomato paste with the addition of Rhizopus oligosporus Koji. Various quality characteristics were determined including proximate composition, physicochemical properties, free sugar and organic acid contents, free amino acid content, total microbial count, enzyme activity, and the presence of volatile compounds. The results showed that the free sugar content of tomato 'Soksungjang' was $14.81 \mathrm{mg} \%$. The individual sugars identified were glucose, galactose, fructose, sucrose, maltose, and lactose. The total organic acid content was $162.79 \mathrm{mg} \%$ and the identified individual organic acids were citric acid, lactic acid, acetic acid, malic acid, formic acid, and succinic acid. The total free amino acid content was $1,440 \mathrm{mg} \%$, including major amino acids, such as glutamic acid, lysine, and arginine. The $\alpha$-amylase activity of the tomato 'Soksungjang' was $\mathbf{7 4 . 4 2} \mathrm{unit} / \mathrm{mL}$, whereas lipase and neutral protease activities were 93.59 and 35.79 unit/mL, respectively. Total 30 compounds including alcohols, esters, ketones, and aldehydes were detected in tomato 'Soksungjang'. Ethyl alcohol, 3-methyl-1-butanol, and ethyl acetate were among the major volatile compounds.
\end{abstract}

Key words : Rhizopus oligosporus, Koji, Soksungjang, quality, tomato

서 론

우리나라의 대두 발효식품은 된장, 고추장 및 간장이 대표 적이며, 이 중 된장은 저장성이 뛰어나고 특유의 향미를 지니 고 있다. 특히 필수아미노산, 지방산, 유기산, 미네랄 및 비타 민 등이 풍부하게 함유되어 있어, 쌀을 주식으로 하는 한국인 의 우수한 단백질 공급원이 되어 왔다(Yang 등, 1994). 다양
한 생리활성 및 영양성분을 가진 된장은 제조방법에 따라 재 래식 된장과 개량식 된장으로 나뉜다. 재래식 된장은 지역에 따라 제조방법에 차이가 있지만 일반적으로 대두를 삶아 찡 고 성형하여 메주를 만든 다음 자연상태에서 미생물을 번식 시켜 소금물에 담가 발효, 숙성시킨 후에 간장을 분리한 것을 말한다(Kim 등, 2000). 일반적으로 개량식 된장은 쌀이나 보 리, 대두를 삶아 Aspergillus oryzae를 접종하여 만든 Koji를

*Corresponding author. E-mail : ykim@jbnu.ac.kr, Phone : +82-63-270-2569, Fax : +82-63-270-2572

Received 19 October 2020; Revised 11 December 2020; Accepted 29 December 2020.

Copyright (c) The Korean Society of Food Preservation.

This is an Open Access article distributed under the terms of the Creative Commons Attribution Non-Commercial License (http://creativecommons.org/licenses/by-nc/4.0) which permits unrestricted non-commercial use, distribution, and reproduction in any medium, provided the original work is properly cited. 
첨가하여 배양시킨 다음 소금을 혼합하고 숙성시킨 후 마쇄 하여 제조된 것을 말한다(Park 등, 1995). 개량식 된장은 입국 에 다량으로 형성된 단백분해효소의 작용으로 인해 대두단백 질이 분해되고 특정 풍미를 지닌다(Chang과 Chang, 2007). 그러나 이러한 재래식 된장과 개량식 된장은 제품 완성까지 수개월의 시간이 소요되며, Aspergillus 속으로부터 유래되는 aflatoxin의 오염 가능성이 있어 건강에 위협을 끼칠 수 있다 고 보고되었다(Bae 등, 2003; Choi 등, 2002). 그에 반해 Rhizopus oligosporus를 이용한 tempeh의 경우, 2-3일의 발 효기간만으로도 충분한 영양학적 가치가 있으며, aflatoxin과 kojic acid를 생산하지 않는다고 보고되었다(Kinosita 등, 1968). 하지만 R. oligosporus를 이용한 장류의 제조에 관한 연구로는 R. oligosporus를 이용한 한국 된장의 제조에 관한 연구(Park, 1987), R. oligosporus를 이용한 캡슐형 메주의 제 조 및 품질 특성(Choi 등, 2002), 귤피를 이용한 속성장의 품 질특성에 관한 연구(Youn 등, 2016) 등이 보고되어 있을 뿐 속성발효에 적합한 R. oligosporus를 이용한 연구사례는 아 직 부족한 실정이다.

속성장은 대두를 주원료로 하여 메주를 다른 방법으로 띄 우거나, 부재료를 섞어 발효기간을 짧게 하는 것으로 지역이 나 부재료의 특성에 맞게 단기간 발효를 거쳐 제조되며, 된장 이나 간장 등과는 구분된다(Youn, 1985). 속성장은 발효기간 이 짧고 식염 함량이 낮은 장점이 있기 때문에 저염 발효 속 성장을 요구하는 소비계층에게는 도움이 될 것이며, 특히 소 비자들의 입맛에 맞는 다양한 종류의 속성장 개발과 이들의 품질 특성연구가 필요한 실정이다.

토마토(tomato, Lycopersicon esulentum Mill.)는 항산화 활 성이 있는 lycopene과 flavonoid, glutamic acid, $\beta$-carotene, 비타민 $\mathrm{C}$, 비타민 E 등 다양한 생리활성 물질을 함유하고 있 다(Tapiero 등, 2004). 토마토는 높은 무기염 함량, 특유의 맛 과 색, 유기산 등 다양한 물질들을 함유하고 있어 주스나 퓨 레, 케첩 또는 페이스트 등 가공용으로 널리 이용되고 있다 (Kattan, 1957). 우리나라에서는 주로 생식이나 주스로 이용 되고 있으며, 요리 및 샐러드에 활용되는 비중 또한 증가하고 있다. 그러나 최근 재배면적 증가에 의한 토마토 과잉 생산 때문에 토마토의 소비촉진 방안이 모색되고 있다(Kim 등, 2017). 토마토를 활용한 연구로는 토마토 김치(Kim와 Hahn, 2006), 토마토분말 첨가 소시지(Na와 Joo, 2012), 토마토 잼 (Na 등, 2012), 토마토 분말 첨가 국수(Kim 등, 2015), 토마 토 장류에 대한 연구는 토마토 퓨레 조청을 함유한 기능성 고추장(Seo 등, 2012), 토마토 발효액을 이용한 고추장의 이 화학적 및 기능적 특성(Yim 등, 2020) 등이 보고되었으나, 토마토를 이용한 된장 및 속성장에 관한 연구는 부족한 실정 이다. 본 연구에서는 우수한 생리활성을 가진 토마토의 이용
방안 증진을 위하여 R. oligosporus Koji를 사용하여 불쾌취 가 감소된 토마토 속성장을 제조하고, 이들의 품질특성을 조 사하였다.

\section{재료 및 방법}

\section{Koji 제조}

대두는 태광 품종을 구입하여 실온에서 12시간 침지 후 $121^{\circ} \mathrm{C}$ 에서 40 분간 증자하여 실온으로 냉각하였다. 쌀은 신동 진 품종을 대형마트에서 구입하여 실온에서 3시간 수침 후 1 시간 동안 증자하여 냉각하였다. 냉각된 쌀과 대두를 $1: 1$ 의 비율로 혼합 후 혼합된 쌀과 대두 무게의 $1 \%(\mathrm{v} / \mathrm{w})$ 비율로 $R$. oligosporus(KCCM 11275)를 접종하였고, $30^{\circ} \mathrm{C}$ 에서 48시간 배양하여 제조하였다.

\section{토마토 속성장 제조}

대두를 정제수로 3 회 세척 후 12 시간 수침하여 탈수한 대 두를 $121^{\circ} \mathrm{C}$ 에서 40 분간 증자하였다. 대두를 실온으로 냉각한 후 마쇄한 콩에 R. oligosporus Koji(삶은 콩 무게의 $3 \%$ ), tomato paste(수분함량 $21.5 \%$, 삶은 콩 무게의 $10 \%$ ), 소금(삶 은 콩 무게의 $5 \%$, 액젓(삶은 콩 무게의 $2 \%$ )을 혼합하여 용 기에 담았다. $25^{\circ} \mathrm{C}$ 에서 3 일간 1 차 발효한 후, $4^{\circ} \mathrm{C}$ 에서 15 일간 숙성시켜 토마토 속성장을 제조하였다. 속성장 제조 시 사용 한 액젓, 토마토는 시내 대형마트에서 완숙된 대과를 구입하 여 깨끗하게 세척하고, 껍질을 벗겨 paste 형태로 만들어 사 용하였으며, 소금은 전남 신안군 염전에서 구입하여 사용하 였다.

\section{일반성분 및 이화학적 특성 분석}

수분함량은 $105^{\circ} \mathrm{C}$ 상압가열건조법으로 측정하였고, 조단 백질 및 총질소는 micro-Kjedahl법, 조지방은 Soxhlet's 추출 법, 조회분은 $550^{\circ} \mathrm{C}$ 직접회화법으로 측정하였다. 탄수화물 함량은 시료의 무게를 $100 \%$ 로 하여 수분, 조회분, 조단백질, 조지방 함량 \%를 제외한 값으로 구하였다. $\mathrm{pH}$ 는 $\mathrm{pH}$ meter (PB-10, Sartorius, Berlin, Germany)로, 적정산도는 $\mathrm{pH}$ 측정 후 $0.1 \mathrm{~N} \mathrm{NaOH}$ 용액을 $\mathrm{pH}$ 8.3이 될 때까지 적정하여 젖산량으로 환산하여 산출하였다. 염도는 염도계(TM-30D, Takemura Electric Works Ltd., Tokyo, Japan)를 이용하였고, 당도는 당 도계(N2, Atago Ltd., Tokyo, Japan)를, 색도는 색차계(CR400, Minolta Co., Ltd., Tokyo, Japan)를 이용하여 Hunter scale에 따라 명도(L), 적색도(a), 황색도(b) 값으로 표시하였 다. 아미노태 질소함량은 Formol법, 환원당은 DNS법(Miller, 1959)에 따라 $540 \mathrm{~nm}$ 에서 흡광도를 구하여 glucose 표준곡 선을 이용하여 그 값을 환산하였다. 


\section{유리당 및 유기산 분석}

유리당 및 유기산 분석을 위해 시료 $5 \mathrm{~g}$ 에 $70 \%$ ethanol $50 \mathrm{~mL}$ 를 넣고 진탕교반한 다음 $80^{\circ} \mathrm{C}$ 에서 1 시간 동안 환류냉 각 추출하여 여과하였다. 3차 증류수를 이용하여 $50 \mathrm{~mL}$ 까지 정용한 후, Sep-Pak $\mathrm{C}_{18}$ cartridge(Waters Assoc, Milford, $\mathrm{MA}, \mathrm{USA})$ 와 $0.22 \mu \mathrm{m}$ membrane filter를 통과시킨 다음 HPLC(Shimadzu 20A, Shimadzu Co., Kyoto, Japan)로 분석 하였다. Column은 Shodex Asahipak NH2P-50 4E(4.6 mm× $250 \mathrm{~mm}$, Shodex, Kawasaki, Japan)를 사용하였다. 이동상은 acetonitrile과 water를 $75: 25(\mathrm{v} / \mathrm{v})$ 의 비율로 분석하였고, column 온도 $35^{\circ} \mathrm{C}$, 유속 $1.0 \mathrm{~mL} / \mathrm{min}$, 주입량 $20 \mu \mathrm{L}$, 검출기 는 RI-detector(RID-10A, Shimadzu)로 분석하였다. 유기산은 ICSep Coregel-87H3(7.8 mm×300 mm, Transgenomic Inc., Omaha, NE, USA) column으로 분석하였다. Column 온도 $35^{\circ} \mathrm{C}$, 유속은 $0.6 \mathrm{~mL} / \mathrm{min}$, 이동상은 $0.008 \mathrm{M} \mathrm{H}_{2} \mathrm{SO}_{4}$ 를 사용 하였고 UV detector로 $210 \mathrm{~nm}$ 에서 분석하였다.

\section{유리아미노산 분석}

유리아미노산은 시료 $5 \mathrm{~g}$ 에 $70 \%$ ethanol $100 \mathrm{~mL}$ 를 가하 고 1 시간 동안 교반 후 $80^{\circ} \mathrm{C}$ 에서 15 분간 가열하였다. 추출액 을 여과하여 남은 잔사에 다시 $70 \%$ ethanol $50 \mathrm{~mL}$ 에 넣고 추출하는 조작을 2 회 반복하였다. 상등액을 모두 합하여 감압 농축 후 diethyl ether $20 \mathrm{~mL}$ 를 가해 물 층을 분리하여 $45^{\circ} \mathrm{C}$ 이 하의 온도에서 감압농축하였다. 여기에 sodium citrate buffer $(\mathrm{pH}$ 2.2)로 희석하여 $0.22 \mu \mathrm{m}$ membrane filter로 여과 후 amino acid analysis system(Sykam S-4300, Eresing, Germany) 으로 분석하였다.

\section{미생물수 측정}

시료 $10 \mathrm{~g}$ 을 $0.1 \%$ peptone water에 10 진법으로 희석한 다 음, 희석액을 총균수의 경우, Nutrient agar(Difco, Becton \& Dickinson Co., Sparks, MD, USA)에 도말하여 $30^{\circ} \mathrm{C}$ 에서 24 시간 배양하고, 효모 및 곰팡이 수는 YM agar(Difco, Becton \& Dickinson Co.)에 도말하여 $25^{\circ} \mathrm{C}$ 에서 3-4일간 배양하였다. 생성된 집락 수는 계수하여 희석배수를 곱하여 총균과 효모 및 곰팡이수를 산출하였다.

\section{효소활성 측정}

조효소액은 시료 $5 \mathrm{~g}$ 에 증류수 $25 \mathrm{~mL}$ 를 넣고 진탕 교반하 여 추출 후 $50 \mathrm{~mL}$ 로 정용하고, 여과지(Advantec 2, Toyo Roshi Kaisha, Ltd., Tokyo, Japan)를 사용하여 여과한 다음 syringe filter $(0.22 \mu \mathrm{m}$ pore size, Futecs Co., Ltd., Daejeon, Korea)를 사용하여 재여과한 것을 조효소액으로 사용하였다. $\alpha$-Amylase 활성 측정을 위해서 $1 \%$ 전분용액과 조효소액
$1 \mathrm{~mL}$ 를 $20^{\circ} \mathrm{C}$ 에서 3 분간 반응시킨 후 3,5-dinitrosalicylic acid $1 \mathrm{~mL}$ 를 넣고 $95^{\circ} \mathrm{C}$ 이상의 항온수조에서 15 분간 반응시켰다. 이후 실온으로 냉각하고 증류수를 혼합한 후 $540 \mathrm{~nm}$ 에서 흡 광도를 측정하였다. 조효소액 $1 \mathrm{~mL}$ 에 의해 분해되는 전분의 $\mathrm{mg}$ 수를 효소활성단위 1 unit으로 하여 시료 $1 \mathrm{~mL}$ 당 환산하 여 표시하였으며, 표준 곡선은 maltose를 이용하였다 (Bernfeld, 1955).

Protease 활성 측정을 위해서 $\mathrm{pH}$ 3과 $\mathrm{pH}$ 7로 조정한 $0.6 \%$ casein 용액 $5 \mathrm{~mL}$ 에 조효소액 $1 \mathrm{~mL}$ 를 혼합하여 $30^{\circ} \mathrm{C}$ 에서 10 분간 반응시켰다. 이후 $0.4 \mathrm{M}$ trichloracetic acid $5 \mathrm{~mL}$ 를 혼합하고 $30^{\circ} \mathrm{C}$ 에서 30 분간 반응시킨 다음 여과하였다. 여액 $2 \mathrm{~mL}$ 에 $0.4 \mathrm{M}$ sodium carbonate $5 \mathrm{~mL}$ 와 Folin reagent 용액 $1 \mathrm{~mL}$ 를 혼합하여 $30^{\circ} \mathrm{C}$ 에서 30 분간 발색한 후 $660 \mathrm{~nm}$ 에서 흡광도를 측정하였다. 조효소액 $1 \mathrm{~mL}$ 에서 1 분간 $1 \mu \mathrm{g}$ 의 tyrosine을 유리할 때 1 unit로 하여 시료 $1 \mathrm{~mL}$ 당 환산하여 표시하였으며, 표준곡선은 L-tyrosine을 이용하여 작성하였 다(Jung 등, 2012).

Lipase 활성 측정을 위해서 대두유와 염을 첨가한 $50 \mathrm{mM}$ phosphate buffer(pH 6.0) $0.9 \mathrm{~mL}$ 에 $0.1 \mathrm{~mL}$ 의 조효소액을 혼 합한 후 $30^{\circ} \mathrm{C}$ 에서 1 시간 동안 반응시켰다. 이후 copper reagent $2 \mathrm{~mL}$ 와 extraction solvent $6 \mathrm{~mL}$ 를 혼합하여 30 분간 진탕교 반하였다. 반응액을 $12,000 \times g$ 에서 원심분리하여 상등액 3 $\mathrm{mL}$ 에 colour regent $0.25 \mathrm{~mL}$ 를 혼합하여 발색시킨 후 440 $\mathrm{nm}$ 에서 흡광도를 측정하였다. 1 분당 $1 \mu \mathrm{mole}$ 의 지방산 생성 량을 시료 $1 \mathrm{~mL}$ 당 1 unit로 환산하여 표시하였으며, 표준곡 선은 linoleic acid를 이용하여 나타내었다(Kim 등, 1984).

\section{향미성분 측정}

향미성분 포집은 AQ-200 liquid sampler(Japan Analytical Industry, Tokyo, Japan)를 이용하였다. 시료관의 온도는 $40^{\circ} \mathrm{C}$ 로 설정하였고, $50 \mathrm{~mL} / \mathrm{min}$ 의 속도로 시료를 bubbling하여 휘발시켜 Tenax GR 흡착관(Japan Analytical Industry)에서 30 분 동안 흡착시켰다. 흡착된 시료는 Purge \& Trap sampler (JTD-505III, Japan Analytical Industry)-GC/MS QP 2010 plus(Shimadzu)를 사용하여 분석하였다. 흡착된 시료를 $280^{\circ} \mathrm{C}$ 에서 30 분 동안 탈착시킴과 동시에 Curio pointer $\left(-40^{\circ} \mathrm{C}\right)$ 에서 재흡착하였고, 재흡착이 끝난 후 $280^{\circ} \mathrm{C}$ 로 pyrolysis시켜 시료를 column에 주입하였다. 그 외 transfer-line temperature $280^{\circ} \mathrm{C}$, needle heater $280^{\circ} \mathrm{C}$, cold-trap heater $200^{\circ} \mathrm{C}$, head press 86 $\mathrm{MPa}$, column flow $1.0 \mathrm{~mL} / \mathrm{min}$, split ratio $1 / 100$ 의 조건으로 분석하였다. 시료의 분석은 GC/MS QP 2010 plus(Shimadzu) 를 사용하였고, 컬럼은 DB-624 column $(30 \mathrm{~m} \times 0.251 \mathrm{~mm} \times$ $1.40 \mathrm{~mm}$; Agilent Technologies, Wilmington, DE, USA)을 사용하였다. Oven temperature program은 $40^{\circ} \mathrm{C}$ for $3 \mathrm{~min}$ 
hold, $10 \mathrm{~mL} / \mathrm{min}$ up to $260^{\circ} \mathrm{C}, 5 \mathrm{~min}$ hold의 조건으로 분석 하였다. 질량분석기의 ion source 온도는 $200^{\circ} \mathrm{C}$, transfer line 은 $250^{\circ} \mathrm{C}$ 및 $\mathrm{EM}$ voltage는 $70 \mathrm{eV}$ 를 사용하였다. Database는 NIST database(Wiley $7.0 \mathrm{v}$ )를 사용하여 정성 분석하였다.

\section{결과 및 고찰}

\section{일반성분 및 이화학적 특성}

R. oligosporus Koji를 이용하여 제조한 토마토 속성장의 일반성분(Table 1) 및 이화학적 특성(Table 2)을 분석한 결 과, 토마토 속성장은 수분함량 $60.59 \%$, 조단백질 $23.64 \%$, 총 질소 $2.91 \%$, 조지방 $2.45 \%$, 조회분 $5.28 \%$ 및 탄수화물 함량 $15.27 \%$ 로 기존에 보고(Jung과 Rho, 2004)된 일반 시판된장 에 비해 높은 단백질 함량과 낮은 지방 및 회분 함량을 지니 는 것으로 나타났다.

토마토 속성장의 $\mathrm{pH}$ 와 적정산도는 각각 5.6 과 $1.3 \%$ 이었 으며, 환원당 함량은 $36.3 \mathrm{mg} \%$ 를 나타내었다. 특히 환원당

Table 1. Proximate composition of tomato 'Soksungjang' prepared with $\boldsymbol{R}$. oligosporus Koji

\begin{tabular}{cc}
\hline Proximate composition & Content (\%) \\
\hline Moisture & $60.59 \pm 0.135$ \\
Crude protein & $23.64 \pm 0.677$ \\
Total nitrogen & $2.91 \pm 0.849$ \\
Crude lipid & $2.45 \pm 0.322$ \\
Crude ash & $5.28 \pm 0.134$ \\
Carbohydrate & $15.27 \pm 0.424$ \\
\hline
\end{tabular}

Table 2. Physicochemical properties of tomato 'Soksungjang' prepared with $\boldsymbol{R}$. oligosporus Koji

\begin{tabular}{|c|c|c|}
\hline \multicolumn{2}{|c|}{ Physicochemical properties } & Values \\
\hline \multicolumn{2}{|l|}{$\mathrm{pH}$} & $5.6 \pm 0.04$ \\
\hline \multicolumn{2}{|c|}{ Titratable acidity (\%) } & $1.3 \pm 0.19$ \\
\hline \multicolumn{2}{|c|}{ Reducing sugar $(\mathrm{mg} \%)$} & $36.3 \pm 0.68$ \\
\hline \multicolumn{2}{|c|}{ Amino nitrogen $(\mathrm{mg} \%)$} & $432.3 \pm 0.28$ \\
\hline \multicolumn{2}{|l|}{ Salinity(\%) } & $4.4 \pm 0.32$ \\
\hline \multicolumn{2}{|l|}{${ }^{\circ}$ Brix } & $8.0 \pm 0.15$ \\
\hline \multirow{3}{*}{ Color value } & $\mathrm{L}$ & $39.1 \pm 0.17$ \\
\hline & $\mathrm{a}$ & $9.3 \pm 0.33$ \\
\hline & $\mathrm{b}$ & $17.1 \pm 0.09$ \\
\hline
\end{tabular}

함량은 쌀된장에서 숙성 20 일째 $10-11 \mathrm{mg} \%$ 함량을 나타낸 Jung 등(1995)의 연구에 비해 높았는데, 이는 토마토 속성장 제조에 사용한 균주인 R. oligosporus의 amylase 높은 활성으 로 인한 것으로 판단된다. 토마토 속성장의 아미노태 질소함 량은 $432.3 \mathrm{mg} \%$ 였으며, 이는 메밀 속성장이 발효 30 일째 242.2-258.2 mg\%를 나타냈다는 연구결과(Choi 등, 2011)에 비해 크게 높은 함량이었다. 아미노태 질소는 된장의 정미성 분으로 발효기간에 따라 그 함량이 증가하는 것으로 알려져 있다(Chang, 2007). 특히, 아미노태 질소함량이 높은 장류는 품질이 좋은 것으로 평가되고 있어, 장류의 품질규격에서 중 요하게 평가된다(Rho 등, 2008). 토마토 속성장의 염도는 $4.4 \%$ 로 측정되었다. 특히, 염도는 초기 담금 시에 $5 \%$ 로 고정 하여 첨가한 염의 농도에 비해 약 $0.5 \%$ 정도 낮아졌으며, 결 과적으로 속성장의 숙성과정에서 발효가 진행됨에 따라 첨 가된 토마토 paste와 같은 부재료들이 영향을 미친 것으로 판단된다. 토마토 속성장의 Hunter 색도는 명도(L) 39.1, 적 색도(a) 9.3, 그리고 황색도(b) 17.1로 측정되었으며, 이는 기 존에 보고(Ahn과 Bog, 2007)된 재래식 된장과 시판된장에 비해 상대적으로 낮은 명도를 나타내었다. 특히, 토마토 속 성장은 짧은 발효 및 숙성기간에도 불구하고, 어두운 붉은색 을 내는 토마토 paste의 첨가로 낮은 명도를 나타낸 것으로 판단된다.

\section{유리당 및 유기산 함량}

R. oligosporus Koji를 이용하여 제조한 토마토 속성장의 유리당 함량(Table 3)은 총 $14.81 \mathrm{mg} \%$ 로 glucose, galactose, fructose, sucrose, maltose와 lactose가 동정되었으며, 그 중 glucose $(9.29 \mathrm{mg} \%)$ 가 속성장의 주요 유리당이었다. Oh 등 (2003)은 시판된장에서 glucose, lactose, ribose, maltose, arabinose, galactose 등의 유리당을 확인하였으며, 이들 중 glucose가 가장 많이 검출되었다고 보고하여 본 연구결과와 유사하였으나, 개별 유리당 함량과 종류에서의 차이는 원료 의 숙성조건과 사용된 균주, 원료 배합비율 등의 차이에서 비 롯된 것으로 판단된다.

토마토 속성장의 유기산 함량(Table 4)은 총 $162.79 \mathrm{mg} \%$ 로, citric acid, lactic acid, acetic acid, malic acid, formic acid, succinic acid가 동정되었고, 그 중 citric $\operatorname{acid}(85 \mathrm{mg} \%)$ 가 토마토 속성장의 주요 유기산이었다. 이는 R. oligosporus Koji를 사용하여 제조한 속성장에서 citric acid, succinic acid, acetic acid 등이 검출되었고, 이들 중 citric acid가 주요 유기산이라고 한 기존의 연구결과(Youn 등, 2016)와 유사하 였으나, 본 연구에서 제조한 토마토 속성장의 경우 개별 유기 산의 함량에 차이가 있었다. 이러한 차이는 속성장 제조 시 첨가된 재료에 의한 유기산의 함량 차이라고 판단된다. 이들 
Table 3. Free sugar content of tomato 'Soksungjang' prepared with R. oligosporus Koji

\begin{tabular}{cc}
\hline Free sugar & Content $(\mathrm{mg} \%)$ \\
\hline Glucose & $9.29 \pm 0.2644$ \\
Galactose & $1.98 \pm 0.0665$ \\
Sucrose & $1.12 \pm 0.1014$ \\
Lactose & $0.24 \pm 0.0450$ \\
Maltose & $0.26 \pm 0.0305$ \\
Fructose & $1.92 \pm 0.1476$ \\
\hline Total & 14.81 \\
\hline
\end{tabular}

Table 4. Organic acid content of tomato 'Soksungjang' prepared with $\boldsymbol{R}$. oligosporus Koji

\begin{tabular}{cc}
\hline Organic acid & Content $(\mathrm{mg} \%)$ \\
\hline Citric acid & $85.00 \pm 0.2644$ \\
Succinic acid & $1.21 \pm 0.0152$ \\
Acetic acid & $27.76 \pm 0.1014$ \\
Malic acid & $12.11 \pm 0.0264$ \\
Lactic acid & $34.79 \pm 0.2193$ \\
Formic acid & $1.92 \pm 0.1476$ \\
\hline Total & 162.79 \\
\hline
\end{tabular}

유기산은 된장에서 산미, 방향 성분, 감미 성분으로서 함량에 따라 된장의 맛 성분에도 영향을 미치며, 특히 succinic acid 와 lactic acid의 경우 상쾌하며 감미로운 신맛을 내는 것으로 보고된 바 있다(Kim과 Rhee, 1993).

\section{유리아미노산}

토마토 속성장의 주요 유리아미노산(Table 5)으로 glutamic $\operatorname{acid}(204.8 \mathrm{mg} \%)$, lysine(140.6 mg\%)과 arginine(134.4 mg\%) 등이 검출되었으며, 총 28 종의 유리아미노산 $(1,440.2 \mathrm{mg} \%)$ 이 확인되었다. 이는 Youn 등(2016)이 R. oligosporus Koji를 이용하여 제조한 귤피 속성장에서 glutamic acid, arginine, leucine, lysine 등의 주요 유리아미노산을 검출하였다는 결과 와 유사하였다. 특히 토마토 속성장은 그들이 R. olligosporus Koji만 사용하여 제조한 속성장과 비교하여 glutamic acid, lysine과 arginine 함량이 크게 증가하였으며, 이는 속성장 제 조 시 첨가된 원료의 배합비율과 숙성기간에 의한 영향으로 판단된다. 된장의 유리아미노산은 숙성과정에서 효소작용으 로 인해 원료로부터 생성되기 때문에 구수하고 단맛을 내는 개별 아미노산들의 함량이 많을수록 맛이 좋으며, 특히 구수
Table 5. Free amino acid content of tomato 'Soksungjang' prepared with $\boldsymbol{R}$. oligosporus Koji

\begin{tabular}{|c|c|}
\hline Amino acid & Content $(\mathrm{mg} \%)$ \\
\hline Phophoserine & 5.6 \\
\hline Taurine & 41.6 \\
\hline Aspartic acid & 39.6 \\
\hline Hydroxyproline & 44.8 \\
\hline Threonine & 42.4 \\
\hline Serine & 66.8 \\
\hline Asparagine & 1.6 \\
\hline Glutamic acid & 204.8 \\
\hline Glycine & 72.0 \\
\hline Alanine & 24.8 \\
\hline$\alpha$-Aminobutyric acid & 87.6 \\
\hline Valine & 46.4 \\
\hline Cystine & 1.2 \\
\hline Methionine & 4.8 \\
\hline Isoleucine & 28.8 \\
\hline Leucine & 89.6 \\
\hline Tyrosine & 44.0 \\
\hline Phenylalanine & 67.2 \\
\hline$\beta$-Alanine & 21.6 \\
\hline$\beta$-Aminoisobutyric acid & 88.8 \\
\hline$\gamma$-Aminobutyric acid & 24.0 \\
\hline Histidine & 20.8 \\
\hline Tryptophan & 1.2 \\
\hline Carnosine & 19.2 \\
\hline Ornithine & 49.6 \\
\hline Lysine & 140.6 \\
\hline Ammonia & 26.4 \\
\hline Arginine & 134.4 \\
\hline Total & $1,440.2$ \\
\hline
\end{tabular}

한 맛은 된장의 풍미적 측면에서 다른 성분에 비해 중요하게 여겨지는 것으로 알려져 있다(Chang과 Chang, 2007). 따라 서 구수하고 단맛을 내는 아미노산을 많이 함유한 재료를 첨 가함으로써 우수한 맛과 영양을 제공하는 속성장을 제조할 수 있을 것으로 판단된다. 


\section{미생물수 및 효소활성}

R. oligosporus Koji를 이용하여 제조한 토마토 속성장의 미생물 수(Table 6)는 총균수의 경우, $6.44 \log \mathrm{CFU} / \mathrm{g}$ 으로 나 타났으며, 이는 Mok 등(2005)이 보고한 $6 \log \mathrm{CFU} / \mathrm{g}$ 과 유사 하였다. Wang 등(1969)은 R. oligosporus가 antibacterial compound를 생산한다고 보고하였으며, 이러한 항균활성 물 질에 영향을 받아 상대적으로 낮은 균수를 나타낸 것으로 판 단된다. 토마토 속성장의 효모 및 곰팡이 수는 $7.72 \log \mathrm{CFU} / \mathrm{g}$ 로 Mok 등(2005)이 보고한 된장의 효모 및 곰팡이 수(6 log $\mathrm{CFU} / \mathrm{g}$ )보다 높게 나타났다. 이는 장류 제조방법의 차이로 토 마토 속성장 제조 시 사용된 재료와 $\mathrm{Koji}$ 의 영향인 것이라 추정된다.

토마토 속성장의 효소활성도를 $\alpha$-amylase, protease와 lipase 로 나누어 조사한 결과(Table 6), $\alpha$-amylase 활성은 74.42 unit $/ \mathrm{mL}$ 로 확인되었다. 이는 Youn 등(2016)이 보고한 $R$. oligosporus Koji를 이용한 속성장의 $\alpha$-amylase 활성(63.47 unit/g)과 귤피 속성장(61.17 unit/g)에 비해 amylase 활성이 높은 것으로 나타났다. 그러나 Lee 등(2012)이 보고한 시판 된장(17.0-675.9 unit/g)에 비해 비교적 낮은 활성을 보였는 데, 이는 된장 제조 시 첨가되는 전분질 원료에 비하여 토마 토 속성장의 경우 전분질 원료가 따로 첨가되지 않기 때문에 $\alpha$-amylase의 활성이 낮은 것으로 판단된다.

토마토 속성장의 protease 활성(Table 6)은 산성에서 13.28 unit $/ \mathrm{mL}$, 중성에서 35.79 unit $/ \mathrm{mL}$ 로 나타났다. 이는 시판된장 에서 중성 protease 활성이 4.0-50.45 unit $/ \mathrm{g}$ 으로 나타난 기존 의 연구결과(Lee 등, 2012)와 비교하여 볼 때, 토마토 속성장 의 짧은 발효기간에도 불구하고 높은 활성을 가진 것으로 확 인되었다. Wang 등(1974)은 R. oligosporus가 생산하는 protease가 A, B, C, D, E의 다섯 가지 형태를 생산하며, $25^{\circ} \mathrm{C}$ 와 $50 \%$ 정도의 수분함량 조건에서 가장 활성이 좋다고 보고 한 바 있다. 이러한 protease 활성은 대두 단백질의 소화성과 영양성 개선에 영향을 미칠 뿐만 아니라, 아미노태 질소 함량

Table 6. Microorganisms and enzyme activities of tomato 'Soksungjang' prepared with $R$. oligosporus Koji

\begin{tabular}{clc}
\hline \multicolumn{3}{c}{ Microorganisms and enzyme activity } \\
\hline $\begin{array}{c}\text { Microorganisms } \\
(\log \text { CFU/g) }\end{array}$ & Aerobic bacteria & $6.44 \pm 0.0039$ \\
& Yeasts and molds & $7.72 \pm 0.0494$ \\
\hline & $\alpha$-Amylase & $74.42 \pm 2.7289$ \\
Enzyme activity & Acidic protease & $13.28 \pm 0.1031$ \\
(unit $/ \mathrm{mL})$ & Neutral protease & $35.79 \pm 0.1645$ \\
& Lipase & $93.59 \pm 0.2516$ \\
\hline
\end{tabular}

과도 연관성이 있으며, 된장 특유의 맛에 영향을 미치는 중요 한 역할을 하는 것으로 알려져 있다(Park, 2004).

토마토 속성장의 lipase 함량은 93.59 unit $/ \mathrm{mL}$ 의 높은 활성 을 가진 것으로 나타났다. 특히, 발효과정 중 lipase의 작용으 로 속성장에 존재하는 triglyceride가 diglyceride, monoglyceride와 유리지방산으로 가수분해되거나 가수분해 산물인 diglyceride와 monoglyceride가 유리지방산과의 결합으로 triglyceride로 합성되기도 하여 lipase의 활성에 영향을 미치 는 것으로 해석된다(Hong 등, 2010; Jung 등, 2009; Kim 등, 2010). 또한, 가수분해된 유리지방산은 효모에 의해 ethyl ester로 분해되어 중요한 향미성분이 되는 한편, 대두에 함유 된 유지는 lipase에 의해 glyceride 이외에도 유리지방산과 휘 발산, ester, 불검화물 등으로 분해되어 풍미에 영향을 미친다 (Kim 등, 2006). 이러한 효소활성 분석결과, R. oligsoporus Koji를 이용한 토마토 속성장은 우수한 protease 및 lipase의 활성으로 인하여 맛과 풍미가 높아져 속성장의 품질 향상에 영향을 미칠 것으로 판단된다.

\section{향미성분}

R. oligosporus Koji를 이용하여 제조한 토마토 속성장의 휘발성 향미성분 분석결과(Table 7), 토마토 속성장에서 동정 된 향미성분은 총 30 여 개로 ethyl alcohol을 포함한 alcohol 류가 9개, 2-propanone을 포함한 ketone류가 10개, ethyl acetate를 포함한 ester류가 8개, aldehyde류가 2개, 그 외에 oleamide가 확인되었다. 이 중 $38.4 \%$ 로 가장 많은 면적을 차 지하는 성분으로 ethyl alcohol이 동정되었으며, 이로 인하여 토마토 속성장의 발효기간 중 알코올 발효 시 생성되는 특유 의 상큼하고 향긋한 향이 생성된 것으로 판단된다. 또한, 일 반적으로 된장 발효 시 생성되는 쿰쿰한 냄새의 원인물질인 butanoic acid가 생성되지 않아 Aspergillus oryzae를 이용하 여 제조한 된장과 차이가 있음을 확인할 수 있었다. Alcohol 류에서 ethyl alcohol 다음으로 $13.22 \%$ 의 3-methyl-1-butanol 이 동정되었는데, 이것은 감미의 바나나 향을 가진 된장 특유 의 냄새로 된장 숙성 중 아미노산 발효로 생성되며, 맥주와 청주에서 고급 알코올 성분으로 중요시되는 물질로 보고되었 다(Choi 등, 2000; Kim 등, 1992).

토마토 속성장의 ester류 중에서는 ethyl acetate가 $12.38 \%$ 로 가장 높은 비율을 차지하였으며, 이것은 주류의 향미성분 에 적은 면적으로도 큰 영향을 미치는 것으로 알려져 있다 (Joung 등, 2004). 특히, ester류 중 가장 높은 면적비율을 차 지한 ethyl acetate는 ethyl alcohol, 3-methyl-1-butanol에 이 어 면적비율이 높아 토마토 속성장의 향미에 영향이 큰 성분 으로 판단된다.

토마토 속성장의 aldehyde류 중에서는 acetealdehyde와 
Table 7. Volatile compounds of tomato 'Soksungjang' prepared with $R$. oligosporus Koji

\begin{tabular}{|c|c|}
\hline \multirow{2}{*}{ Compounds } & Peak area $(\%)$ \\
\hline & Tomato 'Soksungjang' \\
\hline \multicolumn{2}{|l|}{ Esters } \\
\hline Ethyl acetate & 12.38 \\
\hline Propanoic acid ethyl ester & 2.34 \\
\hline Acetic acid methyl ester & 4.10 \\
\hline Acetic acid propyl ester & 2.04 \\
\hline Acetic acid butyl ester & 0.96 \\
\hline Acetic acid isobutyl ester & 1.29 \\
\hline 2-Methylbutyl acetate & 0.52 \\
\hline Isoamyl acetate & 4.12 \\
\hline \multicolumn{2}{|l|}{ Aldehydes } \\
\hline Acetaldehyde & 1.14 \\
\hline 3-Methylbutanal & 0.26 \\
\hline \multicolumn{2}{|l|}{ Ketones } \\
\hline 2-Propanone & 2.11 \\
\hline 2-Pentanone & 0.31 \\
\hline 5-Nonanone & 0.38 \\
\hline Phenyl methyl ketone & 0.35 \\
\hline 1-(2,4-Dimethyl-furan-3-yl)-ethanone & 0.29 \\
\hline 3-Hexanone & 0.36 \\
\hline 2-Hexanone & 0.76 \\
\hline 3-Heptanone & 1.98 \\
\hline 3-Octanone & 0.72 \\
\hline 2-Octanone & 0.50 \\
\hline \multicolumn{2}{|l|}{ Alcohols } \\
\hline Ethyl alcohol & 38.4 \\
\hline 1-Propanol & 0.51 \\
\hline 2-Methyl-2-propanol & 0.30 \\
\hline Isobutyl alcohol & 4.06 \\
\hline 1-Butanol & 0.44 \\
\hline 3-Methyl-1-butanol & 13.22 \\
\hline 2-Methyl-1-butanol & 2.64 \\
\hline 1-Octen-3-ol & 0.75 \\
\hline Hydroxycitronellol & 0.73 \\
\hline \multicolumn{2}{|l|}{ Others } \\
\hline Oleamide & 2.04 \\
\hline Total & 100 \\
\hline
\end{tabular}

3-methylbutanalo이 각각 1.14 와 $0.26 \%$ 로 미량 동정되었다. Acetealdehyde는 효모 발효와 열화학 반응으로 생성되며, 과 실향이나 풀 향을 내고 3-methylbutanal은 사과향을 내는 것 으로 알려져 있다(Choi 등, 2000). 그러나 토마토 속성장에서 aldehyde류는 종류가 적고, 면적비율도 낮아 향미에 큰 영향 을 미치지 않는 것으로 판단된다.

결과적으로 R. oligosporus Koji를 이용한 토마토 속성장 의 향미성분 분석을 통하여 속성장의 불쾌취를 감소시킴으로 써 속성장을 다양한 식품에 적용할 수 있으며, 특히 단일 속 성장으로 소비할 수 있을 뿐만 아니라, 소스의 기본재료로 사 용하여 다양한 제품을 생산할 수 있을 것으로 기대된다.

\section{요 약}

본 연구에서는 Rhizopus oligsporus Koji를 이용하여 제조 한 토마토 속성장의 품질특성을 조사하고자 이화학적 성분, 유리당, 유기산, 유리아미노산, 효소활성, 총균수 및 향미성 분을 분석하였다. 토마토 속성장은 수분함량 $60 \%$, 조단백질 $24 \%$, 총질소 $3 \%$, 조지방 $2.5 \%$, 조회분 $5.3 \%$, 탄수화물 함량 $15.2 \%$ 를 나타내었다. 또한, 토마토 속성장의 $\mathrm{pH}$, 적정산도, 당도, 염도, 환원당과 아미노태 질소 함량은 각각 5.62 , $147.4(\mathrm{~g}$ of $0.1 \mathrm{~N} \mathrm{NaOH}), 8{ }^{\circ} \mathrm{Brix}, 4.43 \%, 36 \mathrm{mg} \%$ 와 244 $\mathrm{mg} \%$ 였다. 토마토 속성장의 유리당으로 glucose, sucrose, fructose, galactose, lactose 및 maltose가 검출되었고, 유기산 으로는 citric acid, malic acid, acetic acid, succinic acid, formic acid 및 lactic acid가 검출되었다. 토마토 속성장의 총 균수는 $6.44 \log \mathrm{CFU} / \mathrm{g}$ 으로 다소 낮은 편이었으나, 효모 및 곰팡이 수는 $7.72 \log \mathrm{CFU} / \mathrm{g}$ 으로 나타났다. $\alpha$-Amylase와 산성 및 중성 protease 활성은 각각 74.72 unit $/ \mathrm{mL}, 13.28$ unit $/ \mathrm{mL}$ 와 $35.79 \mathrm{unit} / \mathrm{mL}$ 이었으며, lipase 활성은 $93.59 \mathrm{unit} / \mathrm{g}$ 으로 높 은 protease와 lipase 활성을 나타내었다. 주요 유리 아미노산 으로는 glutamic acid, lysine, arginine, phenylalanine, serine 등이 검출되었다. 향미성분 분석 결과, 총 30 여 개의 성분이 확인되었는데, alcohol류 9가지, ketone류 10가지, ester류 8 가지, aldehyde류 2가지, 기타 1가지가 동정되었고, 주요 성 분으로는 ethyl alcohol, 3-methyl-1-butanol, ethyl acetate가 검출되었다. 이상의 결과를 통해 R. oligosporus의 높은 단백 질 분해능과 지질 분해능을 확인하였고, 토마토의 첨가는 속 성장의 향미나 식미 등의 관능적 요인에 도움이 될 것으로 기대된다.

\section{감사의 글}

본 연구는 (재)발효미생물산업진흥원 지역 농식품선도클 
러스터 육성사업(제목: 동부권 연계 제품개발(쌈장, 토마토된 장 및 고추장 관련 응용제품)에 의해 수행되었으며, 이에 감 사드립니다.

\section{Conflict of interests}

The authors declare no potential conflict of interest.

\section{ORCID}

Sung-Hee Jeon https://orcid.org/0000-0002-3039-9230

Young-Soo Kim https://orcid.org/0000-0003-1308-4453

\section{References}

Ahn SC, Bog HJ. Consumption pattern and sensory evaluation of traditional Doenjang and commercial Deonjang. Korean J Food Culture, 22, 633-644 (2007)

Bae SI, Kwak BY, Park YK, Kim YH, Shon DH. Survey of aflatoxin $B_{1}$ in domestic Donejang and Kochujang determined by enzyme linked-immunosorbent assay. J Fd Hyg Safety, 18, 95-100 (2003)

Bernfeld P. Amylase, $\alpha$ and $\beta$. Methods Enzymol, 1, 149-158 (1955)

Chang M, Chang HC. Characteristics of Bacterial-Koji and Doenjang (Soybean paste) made by using Bacillus subtilis DJI. Kor J Microbiol Biotechnol, 35, 325-333 (2007)

Choi JY, Lee TS, Noh BS. Characteristics of volatile flavor compounds in Kochujangs with Meju and soybean Koji during fermentation. Korean J Food Sci Technol, 32, 1035-1042 (2000)

Choi JH, Kim MH, Shon MY, Park SK, Choi SD, U H. Production and quality properties of capsule type Meju prepared with Rhizopus oligosporus. Korean J Food Preserv, 9, 315-320 (2002)

Choi HS, Lee SY, Baek SY, Koo BS, Yoon HS, Park HY, Yeo SH. Quality characteristics of Buckwheat (Fagopyrum esculentum) Soksungjang. Korean J Food Sci Technol, 43, 77-82 (2011)

Hong SC, Choi KS, Lee HJ, Kwon DJ. Effects of Deodeok contents on the qualities of quick fermented Doenjang type product. J Korean Soc Food Sci Nutr, 39, 757-763 (2010)
Joung EJ, Peak NS, Kim YM. Studies on Korean Takju using the by-product of rice milling. Korean $\mathrm{J}$ Food Nutr, 17, 199-205 (2004)

Jung SW, Kim YS, Chung KS. Effects of preparation methods and aging temperatures on the properties of rice-Doenjang. Agric Chem Biotechnol, 38, 83-89 (1995)

Jung BM, Rho SB. Physicochemical quality comparison of commercial Doenjang and traditional green tea Doenjang. J Korean Soc Food Sci Nutr, 33, 132-139 (2004)

Jung HK, Jeong YS, Youn KS, Kim DI, Hong JH. Quality characteristics of soybean paste (Doenjang) prepared with Bacillus subtilis DH3 expressing high protease levels, and deep-sea water. Korean J Food Preserv, 16, 348-354 (2009)

Jung JB, Choi SK, Jeong DY, Kim YS, Kim YS. Effects of germination time of soybeans on quality characteristics of Cheonggukjang fermented with an isolated bacterial strain. Korean J Food Sci Technol, 44, 69-75 (2012)

Kattan AA. Changes in color and firmness during ripening of detached tomatoes, and the use of a new instrument for measuring firmness. Proc Am Soc Hortic Sci, 70, 379-383 (1957)

Kim CJ, Cheigh HS, Byun SM. A simple and modified photometric method for measuring lipase activity. Korean J Food Sci Technol, 16, 251-253 (1984)

Kim DS, Ahn JB, Choi WK, Han GP, Park ML, Kang BN, Kim DH, Choi SH. Quality characteristics of noodles added with tomato powder. Culi Sci Hos Res, 21, 129-142 (2015)

Kim EJ, Hahn YS. Preparation of tomato kimchi and its characteristics. Korean J Food Cookery Sci, 22, 535544, (2006)

Kim GE, Kim MH, Choi BD, Kim TS, Lee JH. Flavor compounds of domestic Meju and Deonjang. J Korean Soc Food Nutr, 21, 557-565 (1992)

Kim MJ, Rhee HS. Studies on the changes of taste compounds during soy paste fermentation (II). Korean J Soc Food Sci, 9, 257-260 (1993)

Kim SH, Kim SJ, Kim BH, Kang SG, Jung ST. Fermentation of Doenjang prepared with sea salts. Korean J Food Sci Technol, 32, 1365-1370 (2000)

Kim JH, Yoo JS, Lee CH, Kim SY, Lee SK. Quality properties of soybean pastes made from Meju with mold producing protease isolated from traditional Meju. J 
Korean Soc Appl Biol Chem, 49, 7-14 (2006)

Kim ML, Park EJ, Jeong JS. Sensory characteristics of Doenjang with added Licorice powder as assessed by response surface methodology. Korean J Food Cookery Sci, 26, 62-71 (2010)

Kim KP, Kim KH, Kim YS, Yook HS. Quality characteristics of crackers with tomato concentrate. J Korean Soc Food Sci Nutr, 46, 77-82 (2017)

Kinosita R, Ishiko T, Sugiyama S, Seto T, Igarasi S, Goetz IE. Mycotoxins in fermented food. Cancer Res, 28, 2296-2311 (1968)

Lee SY, Kim IS, Park SL, Lim SI, Choi HS, Choi SY. Antidiabetic activity and enzymatic activity of commercial Doenjang certified for traditional foods. KSBB J, 27, 361-366 (2012)

Miller GL. Use of dinitrosalicylic acid reagent for determination of reducing sugar. Anal Chem, 31, 426-428 (1959)

Mok CK, Song KT, Lee JY, Park YS, Lim SB. Changes in microorganisms and enzyme activity of low salt soybean paste (Deonjang) during fermentation. Food Eng Prog, 9, 112-117 (2005)

Na YM, Lee YJ, Chun SS. Quality characteristics of tomato jam added with fructo-oligosaccharides. J Korean Soc Food Sci Nutr, 41, 227-232 (2012)

$\mathrm{Na}$ YR, Joo NM. Processing optimization and antioxidant activity of sausage prepared with tomato powder. Korean J Food Cookery Sci, 28, 195-206 (2012)

Oh HJ, Moon HK, Kim CS. Development of yeast leavened pan bread using commercial Doenjangs (Korean soybean pastes): 1. Physicochemical properties of Doenjang and physical properties of bread added with Doenjang. J Korean Soc Food Sci Nutr, 32, $1002-1010$ (2003)

Park HS. Studies on Korean Doenjang manufacture with Rhizopus oligosporus. MS Thesis, Sookmyung Women's University, Korea, p 1-58 (1987)

Park JS, Lee MY, Lee TS. Compositions of sugars and fatty acids in soybean paste (Doenjang) prepared with different microbial sources. J Korean Soc Food Nutr, 24, 917-924 (1995)

Park GS. Cookwise approach of slow food: Focused on traditional fermented sauces. Korean J Soc Cookery Sci, 20, 317-334 (2004)

Rho JD, Choi SY, Lee SJ. Quality characteristics of soybean pastes (Doenjang) prepared using different types of microorganisms and mixing ratios. Korean $\mathrm{J}$ Food Cookery Sci, 24, 243-250 (2008)

Seo MJ, Kang BW, Park JU, Kim MJ, Lee HH, Kim ZS, Yoo MB, Kim HS, Kim SM, Jeong YK. Characterization analysis of functional Gochujang including grain syrup with tomato puree. J Life Sci, 22, 1463-1469 (2012)

Tapiero H, Townsend DM, Tew KD. The role of carotenoids in the prevention of human pathologies. Biomed Pharmacother, 58, 100-110 (2004)

Wang HL, Ruttle DI, Hesseltine CW. Antibacterial compounds from a soybean product fermented by Rhizopus oligosporus. Proc Soc Exp Biol Med, 131, 579-583 (1969)

Wang HL, Vespa JB, Hesseltine CW. Acid protease production by fungi used in soybean food fermentation. Appl Microbiol, 27, 906-911 (1974)

Yang SH, Choi MR, Ji WD, Chung YG, Kim JK. The quality of Doenjang (soybean paste) manufactured with Bacillus brevis. J Korean Soc Food Nutr, 23, 980-985 (1994)

Yim EJ, Jo SW, Jeong DY. Physicochemical and functional properties of Gochujang with fermented tomato products. Korean J Food Sci Technol, 52, 183-190 (2020)

Youn SS. Korean Food (History and Cusine). 4th ed, Suhaksa, Seoul, Korea, p 54-59 (1985)

Youn Y, Jeon SH, Yoo JH, Jeong DY, Kim YS. Quality characteristics of tangerine peel Soksungjang prepared from different Koji strains. Korean J Food Preserv, 23, 117-126 (2016) 